\title{
Genetic diversity in Mentha cervina based on morphological traits, essential oils profile and ISSRs markers
}

\author{
Leandra Rodrigues ${ }^{\mathrm{a}, *}$, Orlanda Póvoa ${ }^{\mathrm{b}}$, Cássio van den Berg ${ }^{\mathrm{c}}$, \\ Ana Cristina Figueiredo ${ }^{\mathrm{d}}$, Margarida Moldão ${ }^{\mathrm{e}}$, Ana Monteiro ${ }^{\mathrm{a}}$ \\ ${ }^{a}$ Centro de Botânica Aplicada à Agricultura (CBAA), Instituto Superior de Agronomia, Technical University of Lisbon, Tapada da Ajuda, \\ 1349-017 Lisboa, Portugal \\ ${ }^{\mathrm{b}}$ Centro Interdisciplinar de Investigação e Inovação (C3i), Escola Superior Agrária de Elvas, Instituto Politécnico de Portalegre, Edificio do \\ Trem Auto, Avenida 14 de Janeiro, 7350-903 Elvas, Portugal \\ ${ }^{\mathrm{c}}$ Departamento de Ciências Biológicas, Universidade Estadual de Feira de Santana, Av. Transnordestina s.n., 44036-900 Feira de Santana, \\ Bahia, Brazil \\ ${ }^{\mathrm{d}}$ Universidade de Lisboa, Faculdade de Ciências de Lisboa, Departamento de Biologia Vegetal, IBB, Centro de Biotecnologia Vegetal, C2, \\ Piso 1, Campo Grande, 1749-016 Lisboa, Portugal \\ ${ }^{\mathrm{e}}$ Centro de Engenharia dos Biossistemas (CEER), Instituto Superior de Agronomia, Technical University of Lisbon, Tapada da Ajuda, 1349- \\ 017 Lisboa, Portugal
}

\section{A R T I C L E I N F O}

\section{Article history:}

Received 25 June 2013

Accepted 11 August 2013

Available online

\section{Keywords:}

Mentha cervina

Morphological trait

Essential oil

Genetic diversity

ISSRs

Conservation genetics

\begin{abstract}
A B S T R A C T
Morphological, phytochemical and genetic differences were studied to evaluate the level and distribution of diversity in twelve populations of the Portuguese endangered medicinal plant Mentha cervina L. Morphological variation was correlated with ecological conditions at the site of origin. Pulegone was the major essential oils compound in all of the populations collected at full flowering (68-83\%), in different growing conditions (51-82\%), and for all the developmental stages studied (47-82\%). Although clusters were defined, the analysis revealed a high chemical correlation among all populations $\left(S_{\text {corr }} \geq 0.95 \%\right)$. Intersimple sequence repeats markers were used to assess the population structure and genetic variation. Populations exhibited a relatively low genetic diversity (PPB $=14.3-64.6 \%$, $\left.H_{\mathrm{e}}=0.051-0.222, I=0.076-0.332\right)$, with high structuring between them $\left(G_{\mathrm{ST}}=0.51\right)$. However, the genetic diversity at species level was relatively high ( $\mathrm{PPB}=97.7 \%$; $H_{\mathrm{e}}=0.320$ ). The levels and patterns of genetic diversity were assumed to result largely from a combination of evolutionary history and its unique biological traits, such as breeding system, clonal growth, low capacity of dispersion and habitat fragmentation. The relatively low genetic diversity in the populations analyzed indicates that the maintenance of their evolutionary potential is at risk if population sizes are maintained and if there is no protection of the habitats.
\end{abstract}

(c) 2013 Elsevier Ltd. All rights reserved.

\section{Introduction}

Genetic variation is fundamentally involved in the ability of a species to adapt to biotic and abiotic changes and in its evolution. Recognition of the levels and distribution of genetic variation within and among populations of a species is the base for development and selection of plant genotypes in breeding programs and increases the understanding of the historical

\footnotetext{
* Corresponding author. Present address: Centro de Biotecnologia Agrícola e Agro-alimentar do Alentejo (CEBAL), Rua Pedro Soares, Apartado 6158, 7801908 Beja, Portugal. Tel.: +351 284314 399; fax: +351 284389048.

E-mail addresses: leandra.rodrigues@cebal.pt, leandra_rodrigues@hotmail.com (L. Rodrigues).
} 
processes underlying the genetic diversity providing information for the management and preservation of endangered and geographically restricted species (Escudero et al., 2003; Shah et al., 2008).

Plants belonging to the genus Mentha L. (Lamiaceae) have evolved in nature through natural hybridization and selection, showing substantial variation in terms of their natural habitats, growth characteristics, and aromas (Franco, 1984; Tutin et al., 1972). They have a substantial importance in the botanical economy and to the pharmaceutical industry, mainly because of the essential oils produced and their antimicrobial properties, used since ancient times for the treatment of many digestive tract diseases and in culinary (İscan et al., 2002).

Mentha cervina L. (commonly known as hart's pennyroyal) is an aromatic plant that is traditionally used in Portugal to flavour food dishes and for its medicinal properties, preventing different gastric disorders and inflammations of the respiratory tract (Monteiro et al., 2007; Póvoa et al., 2006; Rodrigues et al., 2008). It has a western steno-Mediterranean distribution, found in France, Portugal, Spain, Morocco, Algeria and it is presumed extinct in Italy (Rhazi and Grillas, 2010). In Portugal it occurs, mainly in river banks and other damp and wet places, which require a longer flooded period that is characteristic of the priority habitat Mediterranean temporary ponds (3170) (Silva et al., 2009). The growth of commercial demands in recent years, the excessive harvesting from the wild, overgrazing and the unfavourable conservation status of their habitats, has shrunk the natural resource of M. cervina to a narrow distribution (Póvoa et al., 2006). Nowadays, it is considered to be decreasing in number and classified as Near Threatened in the IUCN Red List of Threatened Species (Rhazi and Grillas, 2010).

Morphological, molecular and biochemical markers are complementary in determining the genetic similarity of inter- and intra-species and the relationship between the populations (Chahal and Gosal, 2002; Kohler and Friedt, 1999). Given the wellknown genus chemical variability, the essential oil composition from cultivated $M$. cervina populations cultivated (Alentejo Region, Portugal) was recently examined (Rodrigues et al., 2008). This study showed no essential oil chemical polymorphism despite the cultivated population's different provenance. A low genetic diversity associated with high differentiation among populations was also observed when M. cervina genetic diversity was assessed by inter-simple sequence repeats (ISSRs) (Rodrigues et al., 2013c).

Given the medicinal and aromatic potential of this species and its current threatened situation, the present study aims at assessing M. cervina genetic diversity level in Portugal based on the combination of molecular, phytochemical and morphological traits and also to provide guidelines for the conservation and sustainable use of this medicinal species.

\section{Materials and methods}

\subsection{Plant material}

A total of 12 populations of $M$. cervina with different geographic origins were included in the analysis. Geographic distances between populations vary from $9 \mathrm{~km}$ (between Mc32 and Mc33) to $450 \mathrm{~km}$ (between Mc33 and Mc43). Vouchers for each population were deposited in the LISI Herbarium (Table 1).

\subsection{Morphological study}

In this study, the 12 populations of $M$. cervina were kept in the same culture conditions, in the essay field at the Elvas Agrarian School (Alentejo), Portugal (Table 1). For each population, 24 plants were employed, in three lanes $1 \mathrm{~m}$ apart. The soil was soft and well drained. Dripping wings for irrigation and fertilization were placed among the lanes throughout their length. The cultural operations, until harvesting, consisted of manual elimination of weeds. For each population, 15 plants

Table 1

Data on collection site and sample type of Mentha cervina populations studied.

\begin{tabular}{|c|c|c|c|c|c|c|c|}
\hline \multirow[t]{2}{*}{ Populations } & \multirow[t]{2}{*}{ Sample type } & \multicolumn{5}{|l|}{ Specific sample collection sites } & \multirow[t]{2}{*}{ Voucher } \\
\hline & & Location & Altitude (m) & Latitude & Longitude & Hydrographic basin & \\
\hline Mc10 & $\mathrm{M} / \mathrm{G} / \mathrm{W} / \mathrm{C} / \mathrm{DS}$ & Ouguela, Campo Maior & 207 & $39^{\circ} 4^{\prime} 54.96^{\prime \prime} \mathrm{N}$ & $7^{\circ} 0^{\prime} 4.33^{\prime \prime} \mathrm{W}$ & Guadiana & $532 / 2005$ \\
\hline Mc32 & $\mathrm{M} / \mathrm{G} / \mathrm{W}$ & Vilar Seco, Miranda do Douro & 725 & $41^{\circ} 31^{\prime} 25.48^{\prime \prime} \mathrm{N}$ & $6^{\circ} 24^{\prime} 5.56^{\prime \prime} \mathrm{W}$ & Douro & $759 / 2008$ \\
\hline Mc33 & $\mathrm{M} / \mathrm{G} / \mathrm{W}$ & Póvoa, Miranda do Douro & 750 & $41^{\circ} 34^{\prime} 22.71^{\prime \prime} \mathrm{N}$ & $6^{\circ} 19^{\prime} 17.53^{\prime \prime} \mathrm{W}$ & Douro & $760 / 2008$ \\
\hline Mc34 & $\mathrm{M} / \mathrm{G} / \mathrm{W}$ & Bagaúste, Peso da Régua & 50 & $41^{\circ} 9^{\prime} 0.41^{\prime \prime} \mathrm{N}$ & $7^{\circ} 45^{\prime} 2.24^{\prime \prime} \mathrm{W}$ & Douro & $761 / 2008$ \\
\hline Mc35 & $\mathrm{M} / \mathrm{G} / \mathrm{W}$ & $\begin{array}{l}\text { Escarigo, Figueira de Castelo } \\
\text { Rodrigo }\end{array}$ & 560 & $40^{\circ} 50^{\prime} 34.73^{\prime \prime} \mathrm{N}$ & $6^{\circ} 49^{\prime} 33.62^{\prime \prime} \mathrm{W}$ & Douro & $762 / 2008$ \\
\hline Mc36 & $\mathrm{M} / \mathrm{G} / \mathrm{W} / \mathrm{C} / \mathrm{DS}$ & Segura, Idanha-a-Nova & 235 & $39^{\circ} 49^{\prime} 11.06^{\prime \prime} \mathrm{N}$ & $6^{\circ} 58^{\prime} 52.99^{\prime \prime} \mathrm{W}$ & Tejo & $763 / 2008$ \\
\hline Mc39 & $\mathrm{M} / \mathrm{G} / \mathrm{W} / \mathrm{C} / \mathrm{DS}$ & Oledo, Idanha-a-Nova & 335 & $39^{\circ} 58^{\prime} 10.64^{\prime \prime} \mathrm{N}$ & $7^{\circ} 18^{\prime} 27.85^{\prime \prime} \mathrm{W}$ & - & $764 / 2008$ \\
\hline Mc41 & $\mathrm{M} / \mathrm{G} / \mathrm{W} / \mathrm{C} / \mathrm{DS}$ & Valência de Alcântara & 313 & $39^{\circ} 28^{\prime} 1.17^{\prime \prime} \mathrm{N}$ & $7^{\circ} 12^{\prime} 24.16^{\prime \prime} \mathrm{W}$ & Tejo & $766 / 2008$ \\
\hline Mc42 & $\mathrm{M} / \mathrm{G} / \mathrm{W}$ & Torrão, Alcácer do Sal & 50 & $38^{\circ} 17^{\prime} 0.32^{\prime \prime} \mathrm{N}$ & $8^{\circ} 13^{\prime} 57.81^{\prime \prime} \mathrm{W}$ & Sado & $767 / 2008$ \\
\hline Mc43 & $\mathrm{M} / \mathrm{G} / \mathrm{W}$ & Entradas, Castro Verde & 154 & $37^{\circ} 44^{\prime} 36.51^{\prime \prime} \mathrm{N}$ & $7^{\circ} 58^{\prime} 44.60^{\prime \prime} \mathrm{W}$ & Guadiana & $768 / 2008$ \\
\hline Mc44 & $\mathrm{M} / \mathrm{G} / \mathrm{W} / \mathrm{C} / \mathrm{DS}$ & La Codosera & 298 & $39^{\circ} 16^{\prime} 48.08^{\prime \prime} \mathrm{N}$ & $6^{\circ} 52^{\prime} 20.89^{\prime \prime} \mathrm{W}$ & Guadiana & $769 / 2008$ \\
\hline Mc45 & $\mathrm{M} / \mathrm{G} / \mathrm{W} / \mathrm{C} / \mathrm{DS}$ & Alburquerque & 234 & $39^{\circ} 11^{\prime} 0.69^{\prime \prime} \mathrm{N}$ & $7^{\circ} 1^{\prime} 59.03^{\prime \prime} \mathrm{W}$ & Guadiana & $770 / 2008$ \\
\hline
\end{tabular}

Morphological study $(\mathrm{M})$; genetic study $(\mathrm{G})$; and phytochemical study from wild grown plants $(\mathrm{W})$, from cultivated $v s$ wild growing conditions $(\mathrm{C})$, and at developmental stages (DS). 
(5 plants per lane) were observed. Because no morphological descriptor list was developed yet for Mentha, morphological variables observed were adapted from the morphological descriptor list developed for Coriander by Diederichsen (1996). In a first stage (2 years observation), 35 morphological variables were scored. Analyses of correlation coefficients between all pairs of morphological variables, cluster analyses and principal components analysis allowed elimination of 24 that had or low discrimination value. In total, 11 morphological variables were scored in this study (Table 2).

Data analysis. Morphological variables discriminant analysis was used to assess the degree of separation of the populations by multivariate measurements and to test the impact of individual variables on the discrimination (Sokal and Rohlf, 1995). The cluster analysis was performed using the unweighted pair-group method with arithmetic average (UPGMA) and the Euclidean distance as the similarity coefficient, in the STATISTICA software (StatSoft). In the discriminant analysis, 15 measurements were used for each population, and in the Cluster analyses the score for each character was the mean value of the 15 measurements.

\subsection{Phytochemical study}

Three populations, from the 20 populations analyzed in Rodrigues et al. (2008) in addition to other 9 populations were included in the present study. To characterize the essential oil composition and identify possible chemotypes, the 12 populations were collected, during the flowering phase, from natural habitats. In order to understand the evolution in essential oil composition and yield along the plant life cycle, and compare cultivated with wild growing conditions, a time-course study was undertaken. In this study, 6 of these populations (15 plants per population), where collected from the wild, transported in containers and transplanted to the essay field at Instituto Superior de Agronomia, Lisbon, Portugal. Plants were planted $50 \mathrm{~cm}$ apart, in $2 \mathrm{~m}^{2}$ plots, and drip irrigated periodically (each 7-10 days). Samples from the 6 populations, in the wild and in the cultivated essay field, were harvested at the vegetative, pre-flowering and full-flowering phases. The essential oils were isolated by hydrodistillation and analyzed by gas chromatography (GC) and gas chromatography-mass spectrometry (GCMS) as reported by Rodrigues et al. (2008). The percentage composition of the oils was computed by the normalization method from the GC peak areas, which were calculated as mean values of two injections of each oil sample, without using response factors. The identity of the components was assigned by comparison of their retention indices, relative to a $C_{9}-C_{17}$ hydrocarbon standard mixture, and with GC-MS spectra from a home-made library, constructed based on the analyses of reference oils, laboratory-synthesized components and commercial available standards.

Data analysis. The essential oils composition was used to determine the relationship between the different samples by cluster analysis using Numerical Taxonomy Multivariate Analysis System (NTSYS-pc software, version 2.2, Exeter Software, Setauket, New York) as reported by Rodrigues et al. (2008).

\subsection{Genetic study}

In this study, DNA extraction and amplification of the 121 individuals (corresponding to the 12 populations) with 10 ISSRs markers, and data analysis was performed as reported by Rodrigues et al. (2013b).

To test the correlation between Nei's genetic distance $(D)$, morphological distance matrix, essential oil composition distance matrix and geographic distances (in km) between populations, Mantel tests (Mantel, 1967) were performed using GenAlex 6 program (Peakall and Smouse, 2006). All matrices were transformed to zero mean and unit variance before performing Mantel tests.

\section{Results and discussion}

\subsection{Morphological study}

The results of assessment between the 11 morphological variables, using statistical analyses, showed that the plant height, stem length and the number of flowers in the first inflorescence variables had maximum coefficient of variance, respectively.

Table 2

Morphological variables examined.

\begin{tabular}{ll}
\hline Morphological variables & Abbreviation and units \\
\hline Plant height & Alt $(\mathrm{cm})$ \\
First basal leaf length & comp1fba $(\mathrm{cm})$ \\
Stem length & comC_tt $(\mathrm{cm})$ \\
First inflorescence leaf length & c_foflor $(\mathrm{cm})$ \\
Stem diameter at the plant base & diam_ba $(\mathrm{cm})$ \\
Stem diameter at the first inflorescence & diam_inf $(\mathrm{cm})$ \\
First basal leaf width & lrg_foba $(\mathrm{cm})$ \\
First inflorescence leaf width & lrg_foi $(\mathrm{cm})$ \\
Number of nodes until first inflorescence & nos_cauP \\
Number of flowers in the first inflorescence & n_flor \\
Number of flowered verticillaster at full flowering & nv_flor \\
\hline
\end{tabular}


The stem diameter at the first inflorescence, the first basal leaf width and length had minimum diversity variance coefficient (Table 3).

Discriminant analysis revealed that the three first functions represented $91 \%$ of the total variation in the data set (Table 3 , Fig. 1). The first discriminant function accounted for $70 \%$ of the total variance, and separated cluster II from the others (Fig. 1 ). The standardized coefficients of function 1 were highest for plant height and stem length parameters. Function 2 represented another $16 \%$ of the total variance and roughly separated cluster I and cluster III from cluster IV (Fig. 1). This function was related to the number of flowers in the basal inflorescence and stem length. Function 3 accounted for $6 \%$ of the total variation and was a number of flowered verticillaster at full flowering and number of nodes until 1st inflorescence function.

Cluster analysis was used to investigate further the inter-relationships of these populations (Fig. 2). The clusters formed were similar to the relationships observed in the discriminant analysis. The results allowed the discrimination of the populations from the north (cluster II) in both, the cluster and the discriminant analysis.

The multivariate taxonomic distance matrix for all traits showed no significant association with geographic distance $(P=0.25, r=0.198)$.

In this study, multivariate analyses revealed a structure in which the populations from the north region (Mc32, Mc33, Mc34 and Mc35) were differentiated from those in the more central-south localities. Nevertheless, the observed trend of morphological variation seems not to be associated with the inter-population distance. Several studies have indicated that morphological variation is apparently the result of an adaptive response to the environment. For example, variation of some traits is associated with a latitudinal and altitudinal range (Kleinschmit, 1993). In the present study, the morphological variation pattern, linked with the short plant height and stem length, suggests adaptation to the contrasting climatic conditions.

\subsection{Phytochemical study}

The essential oil yield, in the 12 wild populations of M. cervina, collected at full flowering ranged from $0.4 \%$ to $1.6 \%$ (w/d.w.), averaging 1.0\% (w/d.w) (Table 4). These values are in accordance with the reported oil yield study by Vázquez Vicente (1981) and with some reported oil yields at full flowering for wild Mentha (Mentha pulegium 1.2\%, Hassanpouraghdam et al., 2011; Mentha arvensis 1.7\%, Mentha piperita 1.2\%, Mentha spicata 1.2\%, and Mentha longifolia 1.0\%, Hussain et al., 2010). In the cultivated populations the essential oil yield at full flowering ranged between 0.3 and 1.1\% (w/w.d.), less than half the yield found (2.4-4.0\% w/d.w.) for cultivated populations in the Alentejo region in the study by Rodrigues et al. (2008). According to Voirin et al. (1990), the oil yield is favoured with higher temperatures, water deficit and higher summer sunshine, which is the case in the Alentejo Region, but not so much in the Lisbon Region, which may explain the difference in the yields found.

Thirty three components were identified, ranging from 92 to $100 \%$ of the total oil composition. The identified oil components are listed in Table 4 in order of their elution on the DB- 1 column, arranged according to the four types of essential oils obtained by agglomerative cluster analysis (Fig. 3), with the lowest and the highest percentages found for each component in each volatile oil type.

Mostly quantitative rather than qualitative variation was observed in all the essential oils analyzed. Oxygen-containing monoterpenes (80-97\%) were dominant in all oils, Table 4. Pulegone was the major compound in all of the populations (68-83\%) at full flowering, followed by isomenthone (0.1-22\%), limonene (3-9\%), and menthone (1-2\%). Cluster analysis (Fig. 3), confirmed a high chemical correlation among all populations $\left(S_{\text {corr }} \geq 0.95 \%\right)$. Even though, two clusters were defined in the bases of isomenthone relative amounts. In cluster I, which included 11 out of the 12 samples, isomenthone ranged from 0.1 to $15 \%$, whereas the one sample cluster II showed a higher percentage (22\%). No correlation was detected between the clusters and the geographical collection site. Sub-cluster a has a relative amount between 0.4 and $7 \%$, sub-cluster b between

Table 3

Summary table obtained by stepwise discriminant analysis and standardized coefficients for the first three discriminant functions based on quantitative values of morphometric plant characters of 12 Mentha cervina populations.

\begin{tabular}{|c|c|c|c|c|c|c|c|}
\hline & \multicolumn{4}{|c|}{ Stepwise discriminant analysis summary } & \multicolumn{3}{|c|}{ Standardized function coefficients } \\
\hline & $N$ & $F$ statistics & $R^{2}$ & Wilks' lambda & Function 1 & Function 2 & Function 3 \\
\hline \multicolumn{8}{|l|}{ Plant traits } \\
\hline Alt & 1 & 65.5 & 0.14 & $610^{-3}$ & -0.798 & & \\
\hline comC_tt & 2 & 39.9 & 0.71 & $510^{-3}$ & -1.094 & 0.552 & \\
\hline n_flor & 3 & 31.2 & 0.20 & $310^{-3}$ & & -0.543 & \\
\hline c_foflor & 4 & 26.0 & 0.27 & $310^{-3}$ & & & \\
\hline nv_flor & 5 & 22.0 & 0.60 & $310^{-3}$ & & & 0.93 \\
\hline nos_cauP & 6 & 19.1 & 0.23 & $310^{-3}$ & & & 0.569 \\
\hline diam_ba & 7 & 16.9 & 0.11 & $310^{-3}$ & & & \\
\hline lrg_foi & 8 & 15.4 & 0.15 & $310^{-3}$ & & & \\
\hline diam_inf & 9 & 14.1 & 0.30 & $310^{-3}$ & & & 0.535 \\
\hline comp1fba & 10 & 12.8 & 0.14 & $310^{-3}$ & -0.209 & & \\
\hline lrg_foba & 11 & 11.9 & 0.16 & $310^{-3}$ & & & \\
\hline \multicolumn{5}{|c|}{ Cumulative variation } & 70.2 & 85.7 & 91.2 \\
\hline
\end{tabular}




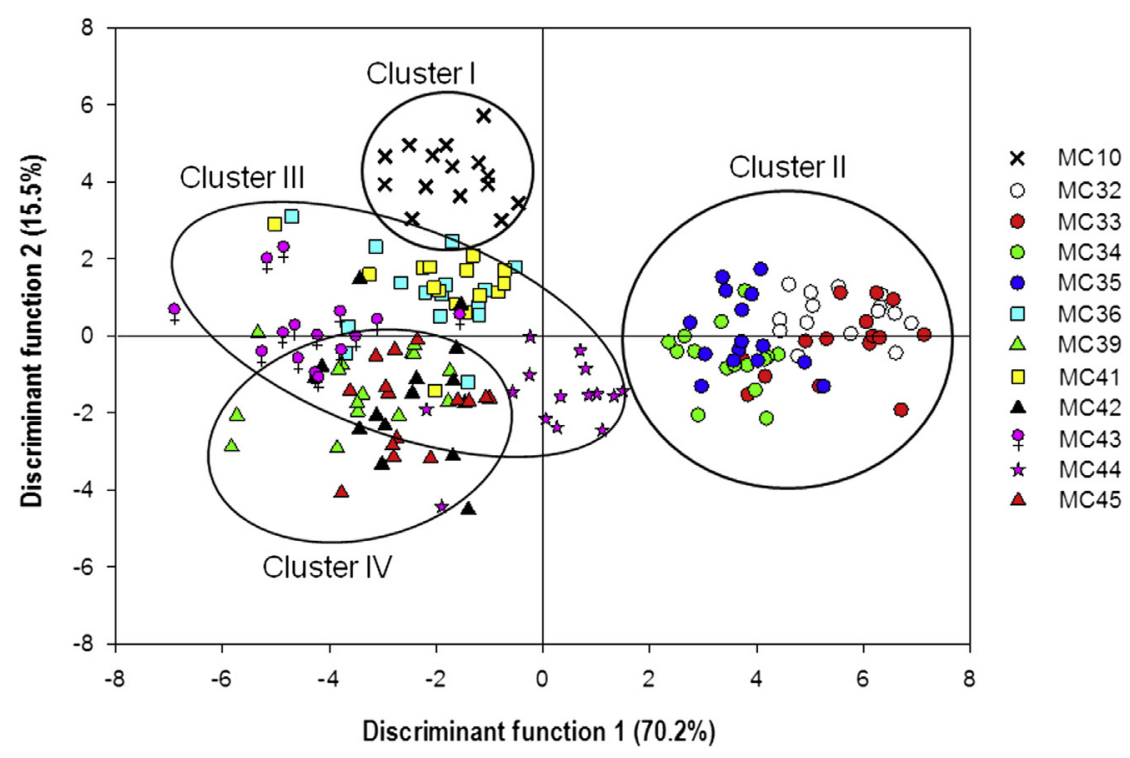

Fig. 1. Discriminant analysis based on the morphological trait in the 12 Mentha cervina populations. For samples grouped on each of the clusters, see Fig. 2.

9 and $15 \%$ and sub-cluster $\mathrm{c}$ (Mc34) has the lower relative amount ( $0.1 \%)$. No significant correlation was detected between the clusters and the geographical collection site $(P=0.070, r=0.301)$.

All the essential oils studied belonged to the pulegone chemotype, in accordance with the results of Rodrigues et al. (2008) on cultivated Portuguese populations collected during the flowering phase. M. cervina essential oils studied until now showed high uniformity, which is not usual in Mentha species and hybrids that are known to have different chemotypes (Kokkini and Vokou, 1989).

In plant developmental terms, the essential oil yield had a different behaviour according to the growing conditions. The yield of the essential oils isolated from wild growing populations increased rapidly from the vegetative stage (mean value $0.4 \% \mathrm{w} / \mathrm{d} . w$. .) until full flowering, June and July (mean value $1.1 \% \mathrm{w} / \mathrm{d} . \mathrm{w}$.). In the cultivated ones, the essential oil yield increased from the vegetative until the pre-flowering phase $(1.2 \% \mathrm{w} / \mathrm{d} . \mathrm{w})$ and then it started to decrease towards the flowering stage $(0.7 \% \mathrm{w} / \mathrm{d} . \mathrm{w}$.).

The analysis of the main essential oil constituents revealed that pulegone remained the major constituent, along the life cycle of the plant, for both growing conditions, although the behaviour of the main components was slightly different (Fig. 4).

In the essential oil isolated from cultivated populations, pulegone relative amount increased from the vegetative until the pre-flowering phase and then it started to decrease towards the full-flowering phase. The pulegone relative amount from wild growing populations increased until the vegetative phase and then stabilized towards the end of the plant life cycle. These changes were followed by changes in the main components relative amounts, whenever the pulegone decreased, the isomenthone and menthone tended to increase (Fig. 4), in particular the isomenthone. Physiological variations (i.e. organ and

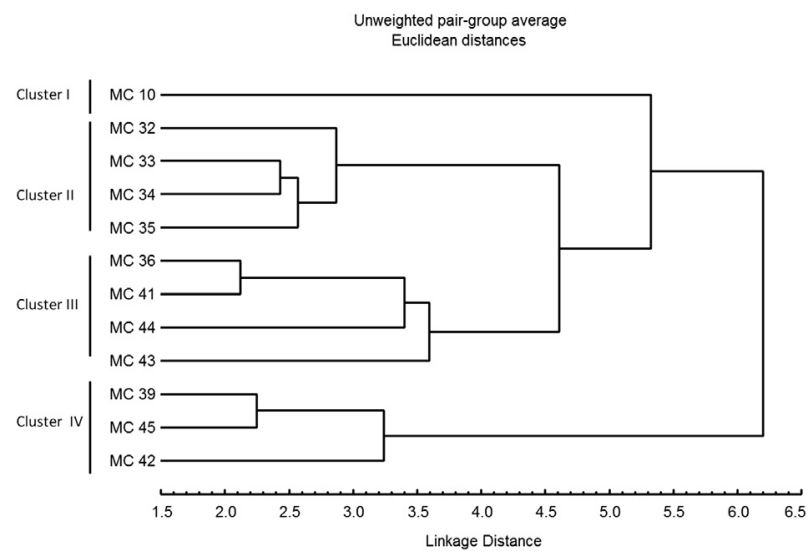

Fig. 2. Hierarchical cluster analysis dendrogram of Euclidean similarity distance showing the relationship among $12 \mathrm{M}$. cervina populations based on average values of morphological variables. 
Table 4

Minimum and maximum percentage range of components identified in the essential oil, isolated from the aerial parts of 12 Mentha cervina wild populations collected at full-flowering phase. For samples grouped on each of the clusters, see Fig. 3.

\begin{tabular}{|c|c|c|c|c|c|c|c|}
\hline \multirow[t]{3}{*}{ Components } & \multirow[t]{3}{*}{ RI } & \multicolumn{5}{|c|}{ Cluster I } & \multirow{3}{*}{$\begin{array}{l}\text { Cluster II } \\
\text { Mc36 }\end{array}$} \\
\hline & & \multicolumn{2}{|l|}{ a } & \multicolumn{2}{|l|}{$\mathrm{b}$} & \multirow{2}{*}{$\frac{\mathrm{c}}{\text { Mc34 }}$} & \\
\hline & & Min & Max & Min & $\operatorname{Max}$ & & \\
\hline 3-Methyl cyclohexanone & 914 & $\mathrm{t}$ & $\mathrm{t}$ & $\mathrm{t}$ & $\mathrm{t}$ & $\mathrm{t}$ & $\mathrm{t}$ \\
\hline$\alpha$-Thujene & 924 & $\mathrm{t}$ & $\mathrm{t}$ & $\mathrm{t}$ & $\mathrm{t}$ & $\mathrm{t}$ & $\mathrm{t}$ \\
\hline$\alpha$-Pinene & 930 & 0.2 & 0.6 & 0.3 & 0.5 & 0.1 & 0.3 \\
\hline Camphene & 938 & $\mathrm{t}$ & $\mathrm{t}$ & $\mathrm{t}$ & $\mathrm{t}$ & $\mathrm{t}$ & $\mathrm{t}$ \\
\hline Sabinene & 958 & $\mathrm{t}$ & 0.4 & 0.1 & 0.2 & 0.2 & 0.1 \\
\hline 3-Octanone & 961 & $\mathrm{t}$ & $\mathrm{t}$ & $\mathrm{t}$ & $\mathrm{t}$ & $\mathrm{t}$ & $\mathrm{t}$ \\
\hline$\beta$-Pinene & 963 & 0.2 & 1.1 & 0.3 & 0.4 & 0.3 & 0.3 \\
\hline 2,5-Dimethyl-1-hexene ${ }^{\mathrm{a}}$ & 970 & $\mathrm{t}$ & $\mathrm{t}$ & $\mathrm{t}$ & $\mathrm{t}$ & $\mathrm{t}$ & $\mathrm{t}$ \\
\hline 3-Octanol & 974 & 0.7 & 1.6 & 1.2 & 1.5 & 1.2 & 1.0 \\
\hline$\beta$-Myrcene & 975 & 0.4 & 1.1 & 0.8 & 1.0 & 0.8 & 0.7 \\
\hline p-Cymene & 1003 & $\mathrm{t}$ & $\mathrm{t}$ & $\mathrm{t}$ & $\mathrm{t}$ & $\mathrm{t}$ & $\mathrm{t}$ \\
\hline 1,8-Cineole & 1005 & $\mathrm{t}$ & $\mathrm{t}$ & $\mathrm{t}$ & $\mathrm{t}$ & $\mathrm{t}$ & $\mathrm{t}$ \\
\hline Limonene & 1009 & 2.6 & 6.7 & 2.8 & 4.8 & 8.6 & 3.1 \\
\hline cis- $\beta$-Ocimene & 1017 & $\mathrm{t}$ & $\mathrm{t}$ & $\mathrm{t}$ & $\mathrm{t}$ & $\mathrm{t}$ & $\mathrm{t}$ \\
\hline trans- $\beta$-Ocimene & 1027 & $\mathrm{t}$ & $\mathrm{t}$ & $\mathrm{t}$ & $\mathrm{t}$ & $\mathrm{t}$ & $\mathrm{t}$ \\
\hline$\gamma$-Terpinene & 1035 & $\mathrm{t}$ & $\mathrm{t}$ & $\mathrm{t}$ & $\mathrm{t}$ & $\mathrm{t}$ & $\mathrm{t}$ \\
\hline n-Octanol & 1045 & $\mathrm{t}$ & $\mathrm{t}$ & $\mathrm{t}$ & $\mathrm{t}$ & $\mathrm{t}$ & $\mathrm{t}$ \\
\hline cis-Linalol oxide & 1045 & $\mathrm{t}$ & $\mathrm{t}$ & $\mathrm{t}$ & $\mathrm{t}$ & $\mathrm{t}$ & $\mathrm{t}$ \\
\hline trans-Limonene oxide & 1112 & $\mathrm{t}$ & $\mathrm{t}$ & $\mathrm{t}$ & $\mathrm{t}$ & $\mathrm{t}$ & $\mathrm{t}$ \\
\hline Menthone & 1120 & 0.6 & 1.7 & 1.0 & 1.6 & 1.2 & 1.8 \\
\hline Isomenthone & 1126 & 0.4 & 6.7 & 9.4 & 15.4 & 0.1 & 21.8 \\
\hline Menthofuran & 1134 & $\mathrm{t}$ & 0.2 & $\mathrm{t}$ & $\mathrm{t}$ & $\mathrm{t}$ & $\mathrm{t}$ \\
\hline cis-Isopulegone & 1134 & 0.5 & 1.6 & 0.3 & 1.1 & 1.0 & 0.9 \\
\hline Terpinen-4-ol & 1148 & $\mathrm{t}$ & $\mathrm{t}$ & $\mathrm{t}$ & $\mathrm{t}$ & $\mathrm{t}$ & $\mathrm{t}$ \\
\hline Verbenone & 1164 & $\mathrm{t}$ & $\mathrm{t}$ & $\mathrm{t}$ & $\mathrm{t}$ & $\mathrm{t}$ & $\mathrm{t}$ \\
\hline Myrtenol & 1168 & $\mathrm{t}$ & $\mathrm{t}$ & $\mathrm{t}$ & $\mathrm{t}$ & $\mathrm{t}$ & $\mathrm{t}$ \\
\hline Pulegone & 1210 & 78.4 & 83.4 & 71.9 & 75.7 & 73.7 & 68.1 \\
\hline Piperitone & 1211 & $\mathrm{t}$ & $\mathrm{t}$ & $\mathrm{t}$ & $\mathrm{t}$ & $\mathrm{t}$ & $\mathrm{t}$ \\
\hline Carvotanacetone $^{\mathrm{a}}$ & 1222 & $\mathrm{t}$ & $\mathrm{t}$ & $\mathrm{t}$ & $\mathrm{t}$ & $\mathrm{t}$ & $\mathrm{t}$ \\
\hline Piperitenone & 1289 & 0.3 & 3.9 & 0.3 & 0.9 & 9.2 & 0.4 \\
\hline$\beta$-Caryophyllene & 1414 & $\mathrm{t}$ & 0.1 & $\mathrm{t}$ & 0.1 & 0.2 & $\mathrm{t}$ \\
\hline$\beta$-Caryophyllene oxide & 1561 & $\mathrm{t}$ & 0.3 & $\mathrm{t}$ & 0.4 & 0.2 & $\mathrm{t}$ \\
\hline Humulene epoxide & 1579 & 0.2 & 1.3 & 0.5 & 1.7 & 0.5 & 0.2 \\
\hline \% Identification & & 97.4 & 99.5 & 98.0 & 99.3 & 92.1 & 98.9 \\
\hline \multicolumn{8}{|l|}{ Grouped components } \\
\hline Monoterpene hydrocarbons & & 3.5 & 9.9 & 4.4 & 6.9 & 10.1 & 4.6 \\
\hline Oxygen-containing monoterpenes & & 80.3 & 97.4 & 82.9 & 94.6 & 85.2 & 93.0 \\
\hline Sesquiterpene hydrocarbons & & $\mathrm{t}$ & 0.1 & $\mathrm{t}$ & 0.1 & 0.2 & $\mathrm{t}$ \\
\hline Oxygen-containing sesquiterpenes & & 0.2 & 1.6 & 0.5 & 2.1 & 0.7 & 0.2 \\
\hline Others $^{\mathrm{b}}$ & & 0.7 & 1.6 & 1.2 & 1.5 & 1.2 & 1.0 \\
\hline Oil yield (v/w) & & 0.9 & 1.5 & 0.7 & 1.6 & 0.4 & 1.1 \\
\hline
\end{tabular}

RI: retention index relative to $\mathrm{C}_{9}-\mathrm{C}_{16} n$-alkanes on the DB-1 column; t: traces $(<0.05 \%)$.

a Identification based on mass spectra only.

b Components that do not fit on the classification of terpene or phenylpropanoid and which are mainly non-aromatic alcohols, ketones and alkenes.

leaf position), environmental conditions (i.e. harvest date and planting time), geographic variations and genetic factors and evolution are known to affect the biosynthesis of the essential oils (Figueiredo et al., 2008). Thus, these type of variations, that where already seen in M. pulegium (Rodrigues et al., 2013a) may be due to the influence of the developmental stage and environmental conditions on the regulation of the essential oil biosynthesis.

\subsection{Molecular study}

ISSR amplification of the 121 individuals, gave a total of 175 bands that could be scored, corresponding to an average of 82.4 fragments per individual. Of these bands, 171 were polymorphic (97.7\%). Genetic diversity estimates from ISSR are summarized in Table 5.

Based on ISSR analysis, the genetic diversity of $M$. cervina at the species level is relatively high $\left(H_{\mathrm{e}}=0.323 ; I=0.226\right.$; PPB $=98 \%$ ), however, in contrast, relatively low genetic diversity occurred at the population level (Table 5). The proportion of polymorphic bands at the population level varied from $14 \%$ to $65 \%$, with a mean of $45 \%$. The least genetically diverse population is Mc34 with 5\% gene diversity and the most diverse populations is Mc43 with 22\% gene diversity (Table 5). These 


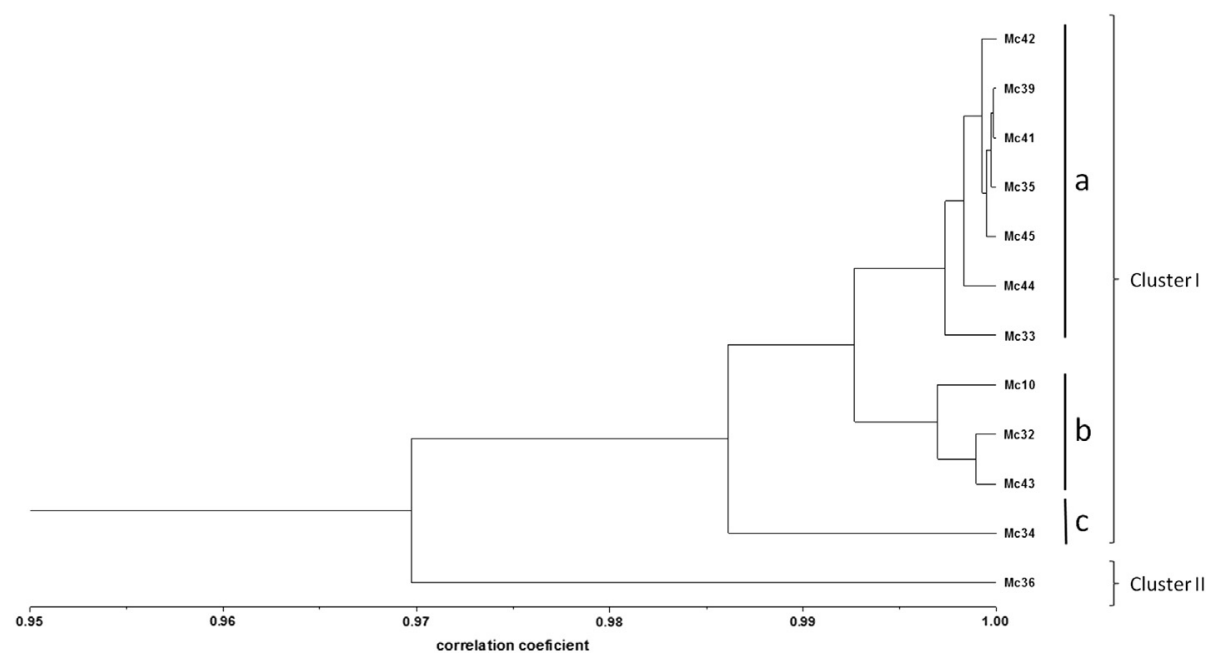

Fig. 3. Dendrogram obtained by cluster analysis of the percentage composition of essential oils from the Mentha cervina samples examined, based on correlation and using the unweighted pair-group method with arithmetic average (UPGMA). For abbreviations, see Table 1.

values are lower than the genetic diversity reported for other Lamiaceae species (Aparicio et al., 2000; Ben Fadhel and Boussaid, 2004; Liu et al., 2006; Mattner et al., 2002) and are consistent with other endangered species (Bin et al., 2005; Jin and Li, 2007; Li and Jin, 2008; Vicente et al., 2011; Wang et al., 2008; Xiao et al., 2004; Zhou et al., 2010).

According to Nei's analysis of gene diversity, the percentages of genetic variation among $M$. cervina populations were 51\% $\left(G_{\text {st }}\right)$ which indicated a high inter-population genetic differentiation. The AMOVA showed that most of the variation was found within populations (52\%) provided additional evidence for the genetic structuring of populations. The nearly $\Phi_{\mathrm{ST}}$ from the AMOVA analysis (0.478) and the $G_{\text {st }}$ from the POPGENE software analysis (Yeh et al., 1997) provide additional support for the robustness of ISSR markers used in this study.

The high level of genetic differentiation $\left(G_{\mathrm{st}}=0.532\right)$ detected among $M$. cervina populations suggest that each population analyzed is genetically defined and structured as a distinct genetic pool. Also, the values of heterozygosity found for the fragments analyzed (0.051-0.222) are lower than the average outcrossing-animal species $\left(H_{\mathrm{e}}=0.260\right)$, and for some of the populations also lower than self-pollinating plants $\left(H_{\mathrm{e}}=0.091\right)$, using RAPD markers (Nybom and Bartish, 2000), which indicates inbreeding within $M$. cervina populations. The reason behind this low heterozygosity may be partly attributed to the clonal growth of this species and the low seed setting and dispersion (Rodrigues et al., 2013b). Clonal growth can significantly decrease the effective population size, and hence contribute to the loss of genetic diversity and the genetic differentiation via increased levels of genetic drift and inbreeding (Erickson and Hamrick, 2003). Also, M. cervina was usually observed in severely fragmented habitats and with small population sizes (from 10 to 1000 individuals), which make this species

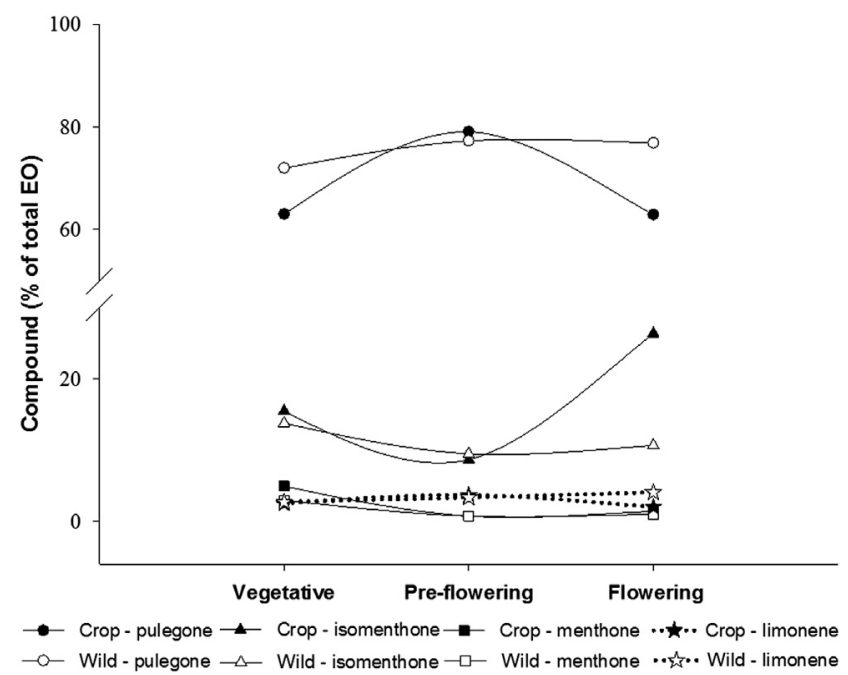

Fig. 4. Time-course study of the main components of the Mentha cervina essential oils isolated in wild (open symbols) and cultivated (closed symbols) growing conditions at different developmental stages. The values are the mean values from 6 populations. 
Table 5

Measures of genetic diversity in each population and the entire data in Mentha cervina. PPB, percentage of polymorphic loci; I, Shannon's information index; $H_{\mathrm{e}}$, Nei's gene diversity.

\begin{tabular}{|c|c|c|c|c|}
\hline \multirow[t]{2}{*}{ Population } & \multicolumn{2}{|l|}{ РPB } & \multirow[t]{2}{*}{ I } & \multirow[t]{2}{*}{$H_{\mathrm{e}}$} \\
\hline & Number & Percentage & & \\
\hline Mc10 & 101 & 57.7 & 0.290 & 0.193 \\
\hline Mc32 & 102 & 58.3 & 0.310 & 0.208 \\
\hline Mc33 & 112 & 64.0 & 0.332 & 0.222 \\
\hline Mc34 & 25 & 14.3 & 0.076 & 0.051 \\
\hline Mc35 & 93 & 53.1 & 0.278 & 0.187 \\
\hline Mc36 & 57 & 32.6 & 0.181 & 0.124 \\
\hline Mc39 & 66 & 37.7 & 0.191 & 0.128 \\
\hline Mc41 & 54 & 30.9 & 0.170 & 0.116 \\
\hline Mc42 & 63 & 36.0 & 0.195 & 0.131 \\
\hline Mc43 & 113 & 64.6 & 0.328 & 0.219 \\
\hline Mc44 & 64 & 36.6 & 0.178 & 0.117 \\
\hline Mc45 & 85 & 48.6 & 0.253 & 0.169 \\
\hline Mean & 78 & 44.5 & 0.232 & 0.155 \\
\hline Total & 171 & 97.7 & & 0.320 \\
\hline
\end{tabular}

extremely vulnerable to stochastic events, genetic drift and inbreeding (Hartl and Clark, 1997), leading to a low genetic diversity and the high genetic structure pattern observed.

To further understand the relationships among populations, a Bayesian analysis with the software STRUCTURE (Pritchard et al., 2000) was used to reveal the number of genetic pools and a cluster analysis (UPGMA) was also used to generate an unrooted tree based on Nei's genetic distances (Fig. 5). The STRUCTURE analyses revealed that the twelve populations of $M$. cervina in the present study share 5 genetic pools, with migrants and admixed individuals. The populations from the north region constitute one gene pool (Mc32, Mc33, Mc34 and Mc35) and grouped together in the UPGMA tree (despite the week

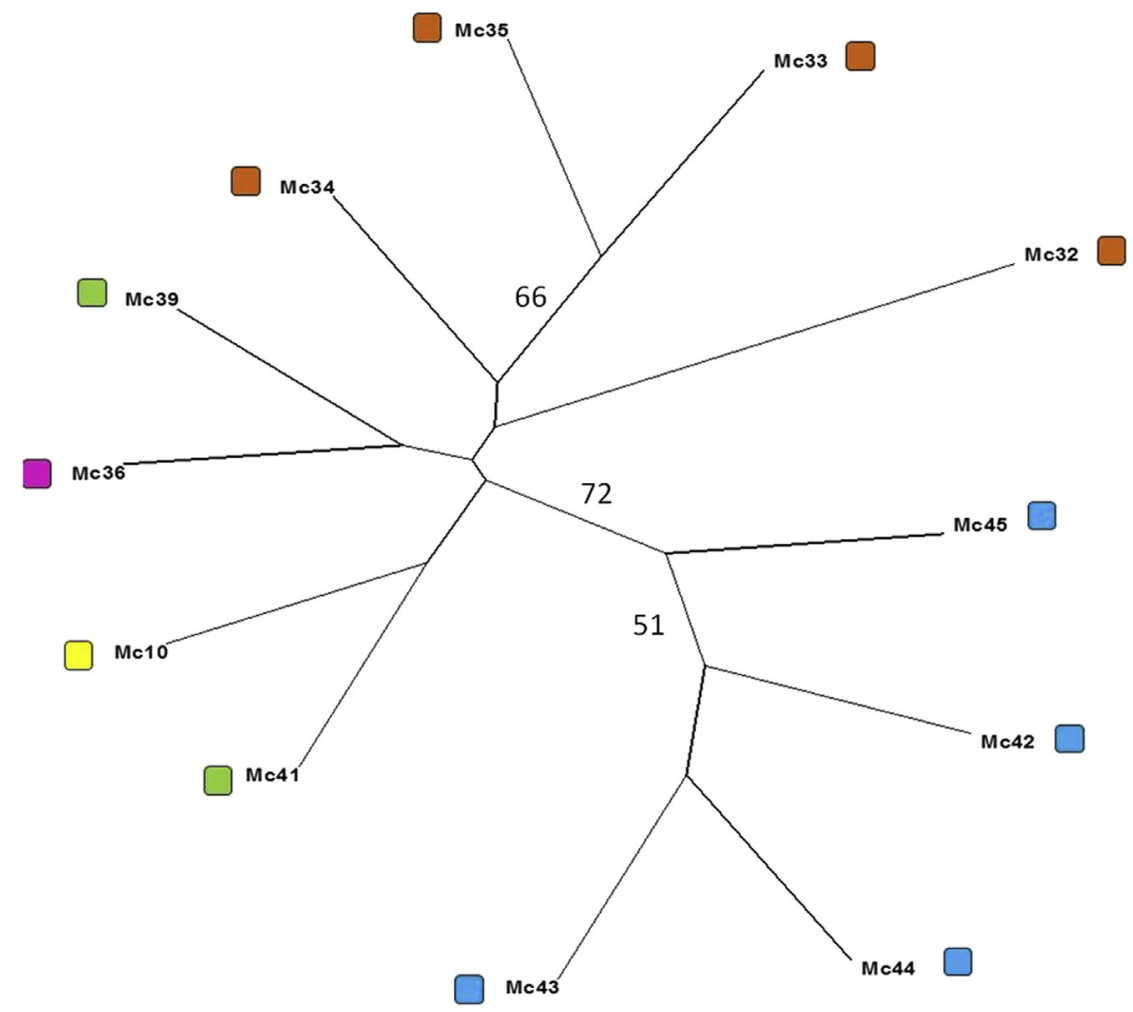

Fig. 5. UPGMA dendrogram based on Nei's genetic distance matrix for Mentha cervina populations. One thousand replicates of bootstrapping analysis were used to assess the statistical support of each branch. Numbers in branches correspond to the bootstrap analyses (50\% or more). Square colour blocks represent the different gene pools according to the STRUCTURE analysis. See Table 1 for population abbreviations. (For interpretation of the references to colour in this figure legend, the reader is referred to the web version of this article.) 
bootstrap support). The two populations from the south share the gene pool with two populations from the centre-south and were also clustered in the UPGMA tree (with moderate bootstrap support) and the other 3 gene pools are encountered in the midland with week and arbitrary clustering (Fig. 5).

On the other hand, Mantel test did not find significant correlation between genetic and geographic distance matrices ( $r=0.031, P<0.5,999$ permutations), indicating that the isolation by distance is not shaping the present $M$. cervina population genetic structure.

\subsection{Correlation between morphological, phytochemical and molecular traits}

The obtained results showed that four populations (Mc32, Mc33, Mc34 and Mc35), out of 12, grouped together, in both the morphological and molecular studies, whereas the essential oils correlation evaluation grouped the populations in an entirely different way (Figs. 2, 3 and 5). Several reasons can determine this different grouping:

ISSRs are considered to be neutral and thus to provide no direct assessment of fitness. The forces that cause differentiation for these markers would be the result of mutation, genetic drift, low gene flow and no selection. Conversely, morphological traits and phytochemical profiles are generally believed to be subject to natural selection, and their expression is partially under the influence of environmental factors (Bruschi et al., 2003). Adding to this, the ISSRs are random markers that show differences in the whole genome, and are not necessarily related to a specific morphological trait or secondary compound. However, previous studies on Salvia fruticosa (Skoula et al., 1999), Ocimum gratissimum (Vieira et al., 2001) Tanacetum vulgare (Keskitalo et al., 2001), Primula ovalifolia (Nan et al., 2003) and Vitex rotundifolia (Hu et al., 2007) reported that the patterns of relatedness observed in chemical profiles seemed to correspond well with the genetic profiles generated by RAPDs and ISSRs. On the other hand, there are also studies, where no correlation could be found among collection site, chemical and molecular analysis (Trindade et al., 2008 in Thymus caespititius). The same pattern of correlations can be observed for the morphological traits. Liu et al. (2007) and Hamza et al. (2004) demonstrated a clear correlation between the morphological traits and the detection of the genetic variability as revealed by RAPD analysis. Conversely, Schut et al. (1997) and Eshraghi et al. (2006) reported a few correlations between the molecular and the morphological traits. Together these studies, suggests that may be there is a genetic basis for the chemical profiles and morphological traits that can be observed with the ISSRs markers, although they are not clear.

At last, although essential oils may evolve more rapidly than morphological traits, the rather unusual uniformity found in the essential oils composition in populations with different geographic provenances, at different developmental stages and in different growing conditions, may explain why the morphological traits were more correlated with the genetic variation, than the phytochemical ones.

From a conservation perspective, the low genetic and phytochemical diversity observed, within the populations tested is symptomatic and a signal that ecological management of $M$. cervina habitats is necessary to prevent the consequent decline in population size that could increase the risk of extinction due to demographic and environmental stochasticity.

\section{Acknowledgements}

The financial support of Fundação para a Ciência e Tecnologia (FCT/CBAA and PhD Grant SFRH/BD/38143/2007 of Leandra Sofia Rodrigues) is gratefully acknowledged.

\section{References}

Aparicio, A., Albaladejo, R.G., Porras, M., Ceballos, G., 2000. Isozyme evidence for natural hybridization in Phlomis (Lamiaceae): hybrid origin of the rare P. $\times$ margaritae. Ann. Bot. 85, 7-12.

Ben Fadhel, N., Boussaid, M., 2004. Genetic diversity in wild Tunisian populations of Mentha pulegium L. (Lamiaceae). Genet. Resour. Crop Evol. 51, 309-321.

Bin, X.Y., Tang, S.Q., Zhou, J.Y., Song, H.T., Li, Z.Y., 2005. ISSR analysis on genetic diversity of Camellia nitidissima Chi (Theaceae) in China. J. Wuhan Bot. Res. 23, 20-26.

Bruschi, P., Vendramin, G.G., Bussotti, F., Grosson, P., 2003. Morphological and molecular diversity among Italian populations of Quercus petraea (Fagaceae). Ann. Bot. 91, 707-716.

Chahal, G.S., Gosal, S.S., 2002. Principles and Procedures of Plant Breeding: Biotechnological and Conventional Approaches, CRC Press, Boca Raton, Fla.

Diederichsen, A., 1996. Coriander (Coriandrum sativum L.). In: Promoting the Conservation and Use of Underutilized and Neglected Crops, vol. 3. Institute of Plant Genetics and Crop Plant Research, Rome, p. 83.

Erickson, D.L., Hamrick, J.L., 2003. Genetic and clonal diversity for Myrica cerifera along a spatiotemporal island chronosequence. Heredity 90, 25-32.

Escudero, A., Iriondo, J.M., Torres, M.E., 2003. Spatial analysis of genetic diversity as a tool for plant conservation. Biol. Conserv. 113, $351-365$.

Eshraghi, P., Zarghami, R., Ofoghi, H., 2006. RAPD analysis of micropropagated plantlets in date palm. Pak. J. Biol. Sci. 9, $111-114$.

Figueiredo, A.C., Barroso, J.G., Pedro, L.G., Scheffer, J.J.C., 2008. Factors affecting secondary metabolite production in plants: volatile components and essential oils. Flavour Frag. J. 23, 213-226.

Franco, J.A., 1984. Nova Flora de Portugal (Continente e Açores), vol. II. Lisboa.

Hamza, S., Hamida, W.B., Rebai, A., Harrabi, M., 2004. SSR-based genetic diversity assessment among Tunisian winter barley and relationship with morphological traits. Euphytica 135, 107-118.

Hartl, D.L., Clark, A.G., 1997. Principles of Population Genetics, third ed. Sinauer, Sunderland.

Hassanpouraghdam, M.B., Akhgari, A.B., Aazami, M.A., Emarat-Pardaz, J., 2011. New menthone type of Mentha pulegium L. volatile oil from Northwest Iran. Czech J. Food Sci. 29, 285-290.

Hu, Y., Zhang, Q., Xin, H., Qin, L.P., Lu, B.R., Rahman, K., Zheng, H., 2007. Association between chemical and genetic variation of Vitex rotundifolia populations from different locations in China: its implication from quality control of medicinal plants. Biomed. Chromatogr. 21, 967-975. 
Hussain, A.I., Anwar, F., Nigam, P.S., Ashrafd, M., Gilanif, A.H., 2010. Seasonal variation in content, chemical composition and antimicrobial and cytotoxic activities of essential oils from four Mentha species. J. Sci. Food Agric. 90, 1827-1836.

İscan, G., Krmer, N., Kürkcüolu, M., Hüsnü, K., Bașer, C., Demrc, F., 2002. Antimicrobial screening of Mentha piperita essential oils. J. Agric. Food Chem. 50, 3943-3946.

Jin, Z.X., Li, J.M., 2007. ISSR analysis on genetic diversity of endangered relic shrub Sinocalycanthus chinensis. Chin. J. Appl. Ecol. 18, $247-253$.

Keskitalo, M., Pehu, E., Simon, J.E., 2001. Variation in volatile compounds from tansy (Tanacetum vulgare L.) related to genetic and morphological differences of genotypes. Biochem. Syst. Ecol. 29, 267-285.

Kleinschmit, J., 1993. Intraspecific variation of growth and adaptive traits in European oak species. Ann. Sci. For. 50, $166-185$.

Kohler, H., Friedt, W., 1999. Genetic variability as identified by AP_PCR and reaction to Sclerotinia sclerotiorum among interspecific sunflower (Helianthus annuus L.) hybrid progenies. Crop Sci. 39, 1456-1463.

Kokkini, S., Vokou, D., 1989. Mentha spicata (Lamiaceae) chemotypes growing wild in Greece. Econ. Bot. 43, $192-202$.

Li, J.M., Jin, Z.X., 2008. Genetic structure of endangered Emmenopterys henryi Oliv. based on ISSR polymorphism and implications for its conservation. Genetica 133, 227-234.

Liu, J., Wang, L., Geng, Y., Wang, Q., Luo, L., Zhong, Y., 2006. Genetic diversity and population structure of Lamiophlomis rotata (Lamiaceae), an endemic species of Qinghai-Tibet Plateau. Genetica 128, 385-394.

Liu, P., Yang, Y.S., Hao, C.Y., Guo, W.D., 2007. Ecological risk assessment using RAPD and distribution pattern of a rare and endangered species. Chemosphere 68, 1497-1505.

Mantel, N., 1967. The detection of disease clustering and a generalized regression approach. Cancer Res. 27, $209-220$.

Mattner, J., Zawko, G., Rossetto, M., Krauss, S.L., Dixon, K.W., Sivasithamparam, K., 2002. Conservation genetics and implications for restoration of Hemigenia exilis (Lamiaceae), a serpentine endemic from Western Australia. Conserv. Biol. 107, 37-45.

Monteiro, A., Póvoa, O., Marinho, S., Rodrigues, L., Monteiro, P., 2007. Mentha pulegium e Mentha cervina, Os Poejos na boa Cozinha Portuguesa. ISA Press, Lisboa.

Nan, P., Peng, S., Shi, S., Ren, H., Yang, J., Zhong, Y., 2003. Interpopulation congruence in Chinese Primula ovalifolia revealed by chemical and molecular markers using essential oils and ISSRs. Z. Naturforsch. 58c, 57-61.

Nybom, H., Bartish, I.V., 2000. Effects of life history traits and sampling strategies on genetic diversity estimates obtained with RAPD markers in plants. Perspect. Plant Ecol. Evol. Syst. 3, 93-114.

Peakall, R.O.D., Smouse, P.E., 2006. GENALEX 6: genetic analysis in Excel. Population genetic software for teaching and research. Mol. Ecol. Notes 6, $288-295$.

Póvoa, O., Farinha, N., Marinho, S., Nunes, P., Godinho, D., Mata, F., Rodrigues, L., Monteiro, A., 2006. Pennyroyal (Mentha pulegium L.) and Hart's Pennyroyal (Mentha cervina L.) biodiversity in Alentejo. Acta Hort. 723, 91-97.

Pritchard, J., Stephens, M., Donnelly, P., 2000. Inference of population structure using multilocus genotype data. Genetics 155, 945-959.

Rhazi, L., Grillas, P., 2010. Mentha cervina. In: IUCN 2011. IUCN Red List of Threatened Species. Version 2011.2 www.iucnredlist.org (downloaded on 31.01.13.).

Rodrigues, L., Monteiro, P., Póvoa, O., Teixeira, G., Moldão, M., Figueiredo, A.C., Monteiro, A., 2008. Morphology of secretory structures and essential oil composition in Mentha cervina L. from Portugal. Flavour Frag. J. 23, 340-347.

Rodrigues, L., Póvoa, O., Teixeira, G., Figueiredo, A.C., Moldão, M., Monteiro, A., 2013a. Trichomes micromorphology and essential oil variation at different developmental stages of cultivated and wild growing Mentha pulegium L. populations from Portugal. Ind. Crop Prod. 43, 692-700.

Rodrigues, L., Berg, C.V.D., Póvoa, O., Monteiro, A., 2013b. Low genetic diversity and significant structuring in the endangered Mentha cervina populations and its implications for conservation. Biochem. Syst. Ecol. 60, 51-61.

Rodrigues, L., Póvoa, O., Teixeira, G., Figueiredo, A.C., Moldão, M., Monteiro, A., 2013c. Low genetic diversity and significant structuring in the endangered Mentha cervina populations and its implications for conservation. Biochem. Syst. Ecol. 50, 51-61.

Schut, J.W., Qi, X., Stam, P., 1997. Association between relationships measures based on AFLP markers, pedigree data and morphological traits in barley. Theor. Appl. Genet. 95, 1161-1168.

Shah, A., Li, D.Z., Möller, M., Gao, L.M., Hollingsworth, M.L., Gibby, M., 2008. Delimitation of Taxus fuana Nan Li \& R.R. Mill (Taxaceae) based on morphological and molecular data. Taxon 57, 211-222.

Silva, V., Póvoa, O., Espírito-Santo, M.D., Vasconcelos, T., Monteiro, A., 2009. Mentha cervina communities in Portugal. Lazaroa 30, 73-79.

Skoula, M., Hilali, I.E., Makris, A.M., 1999. Evaluation of the genetic diversity of Salvia fruticosa Mill. clones using RAPD markers and comparison with the essential oil profiles. Biochem. Syst. Ecol. 27, 559-568.

Sokal, R.R., Rohlf, F.J., 1995. Biometry. W.H. Freeman \& Co, San Francisco.

Trindade, H., Costa, M.M., Lima, A.S.B., Pedro, L.G., Figueiredo, A.C., Barroso, J.G., 2008. Genetic diversity and chemical polymorphism of Thymus caespititius from Pico, São Jorge and Terceira islands (Azores). Biochem. Syst. Ecol. 36, 790-797.

Tutin, T.G., Heywood, V.H., Burges, N.A., Moore, D.M., Valentine, D.H., Walters, S.M., Webb, D.A., 1972. Diapensiaceae to Myoporaceae. In: Flora Europaea, vol. 3. Cambridge University Press, Cambridge.

Vázquez Vicente, C., 1981. Estudio de la Esencia de Preslia cervina Eres. (Labiadas). Tesina. Facultad de Farmacia, Universidad Complutense de Madrid.

Vicente, M.J., Segura, F., Aguado, M., Migliaro, D., Franco, J.A., Martínez-Sánchez, J.J., 2011. Genetic diversity of Astragalus nitidiflorus, a critically endangered endemic of SE Spain, and implications for its conservation. Biochem. Syst. Ecol. 39, 175-182.

Vieira, R.F., Grayer, R.J., Paton, A., Simon, J.E., 2001. Genetic diversity of Ocimum gratissimum L. based on volatile oil constituents, flavonoids and RAPD markers. Biochem. Syst. Ecol. 29, 287-304.

Voirin, B., Brun, N., Bayet, C., 1990. Effect of day length on the monoterpene composition of leaves of Mentha $\times$ piperita. Phytochemistry 29, 749-755.

Wang, C., Zhang, H., Qian, Z.Q., Zhao, G.F., 2008. Genetic differentiation in endangered Gynostemma pentaphyllum (Thunb.) Makino based on ISSR polymorphism and its implications for conservation. Biochem. Syst. Ecol. 36, 699-705.

Xiao, L.Q., Ge, X.J., Gong, X., Hao, G., Zheng, S.X., 2004. ISSR variation in the endemic and endangered plant Cycas guizhouensis (Cycadaceae). Ann. Bot. 94, $133-138$.

Yeh, F.C., Yang, R., Boyle, T., 1997. POPGENE. Version 1.32. Ag/For Molecular Biology and Biotechnology Centre, University of Alberta and Center for International Forestry Research.

Zhou, T.H., Qian, Z.Q., Li, S., Guo, Z.G., Huang, Z.H., Liu, Z.L., Zhao, G.F., 2010. Genetic diversity of the endangered Chinese endemic herb Saruma henryi Oliv. (Aristolochiaceae) and its implications for conservation. Popul. Ecol. 52, 223-231. 